
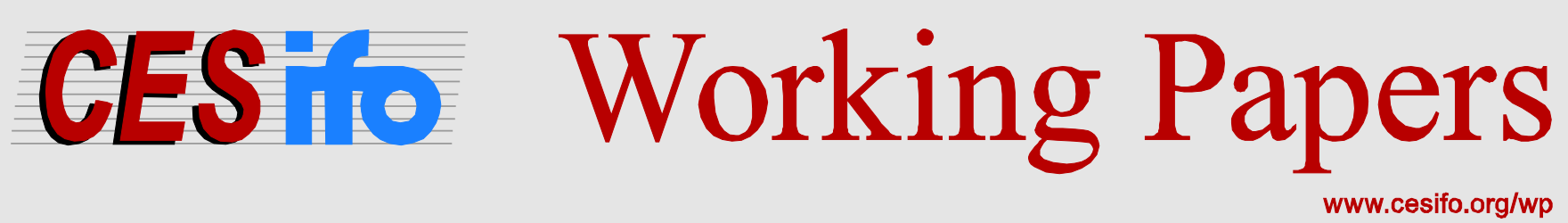

\title{
Immediate Manager Gender and Female Wages - The Importance of Manager Position
}

\author{
Karin Halldén \\ Jenny Säve-Söderbergh \\ Åsa Rosén
}

CESIFO WORKING PAPER NO. 5700

CATEGORY 4: LABOUR MARKETS

JANUARY 2016

An electronic version of the paper may be downloaded

- from the SSRN website:

- from the RePEc website:

- from the CESifo website: WwW.SSRN.com

www.RePEc.org

www.CESifo-group.org/wp

ISSN 2364-1428 


\title{
Immediate Manager Gender and Female Wages - The Importance of Manager Position
}

\begin{abstract}
One argument for increasing female representation in management is the anticipation that female managers are particularly beneficial for female employees through, e.g., role modeling or mentoring. Contrary to the expected positive association, we find that female wages are negatively associated with working directly for a female as opposed to male manager using a representative sample of matched employee-employer data from Sweden. However, dividing the sample by managerial position, and controlling for important sorting of employees, the negative association is found only among lower-level managers and not among high-level managers. We discuss decision-making power as one possible explanation for this heterogeneity.
\end{abstract}

JEL-codes: J160, J310, J530, J710.

Keywords: gender of manager, female wages, immediate manager.

\author{
Karin Halldén \\ Stockholm University \\ (SOFI) \\ Stockholm / Sweden \\ Karin.Hallden@sofi.su.se
}

\author{
Jenny Säve-Söderbergh \\ Stockholm University \\ (SOFI) \\ Stockholm / Sweden \\ Jenny.Save-Soderbergh@sofi.su.se
}

\author{
Åsa Rosén \\ Stockholm University \\ (SOFI) \\ Stockholm / Sweden \\ Asa.Rosen@sofi.su.se
}

We have benefitted from comments from Mike Burkart, Karin Hederos Eriksson, Marianne Sundström, Mikael Tåhlin, participants at SPaDE seminar 2013 and ECSR conference in Tilburg 2013. Financial support from Riksbankens Jubileumsfond and Jan Wallander and Tom Hedelius' Foundation are gratefully acknowledged. 


\section{Introduction}

Several countries are discussing how to improve the position of women in society, in particular in the labor market. One policy has been to implement gender quotas in top positions or on corporate boards. In addition, the vice president of the European Commission has proposed legislation enforcing gender quotas in all European countries. The underlying argument is often that the gender of the manager or the gender composition of the managers affect organizations' workings, their performance as measured by profits and stock prices, and career prospects of female employees. Increasing female representation among managers and superiors is suggested to ameliorate the position of women in the workplace and to increase women's wages and promotion rates through three broadly categorized avenues. The first avenue is through preferences of the manager. For example, if, following theories of homophily, individuals tend to prefer others like themselves (e.g., McPherson et al. (2001); Jackson 2010), then women achieve better outcomes, such as wages and positions, under a female manager, all else being equal. Similarly, if male managers or employers have a taste for discrimination against females, women obtain better wage outcomes under a female manager (e.g., Becker 1971; Rosén 2003). The second avenue is through a productivity-enhancing effect that female managers have on female employees because of better communication, mentoring, being role models, or facilitated social networking (e.g., Brown-Johnson and Scandura 1994; Akerlof and Kranton 2000; Athey et al. 2000). The third avenue is through female managers directly influencing firm structures, such as wage and promotion policies or resource allocation, to be more female- or family-friendly. In addition, it has been argued that managers and executives' gender may directly affect organizations because women and men have differences in personality traits such as attitudes towards risk and willingness to compete (see Bertrand 2011 for an overview).

Empirical assessments of the effects of female representation at firms' top levels, such as female management, gender diversity in boardrooms, organizations 
being female-led, or the proportion of females among top managers, have recently attracted a great deal of interest. Regarding the effect on wage outcomes for female employees this research provides mixed evidence. ${ }^{1}$ The studies assessing how working directly for a female as opposed to male manager provide some support for a negative association between female wages and reporting to a female as opposed to male manager (Srivastava and Sherman 2015; Rothstein 1997). Studies that evaluate the association between female wages and the share of female managers in the organization, however, commonly finds no association, or a positive association, between female wages and the share of female managers in the organization or board room (Hultin and Szulkin 1999; Hensvik 2014; Bertrand et al. 2014). Finally, working in a female as opposed to male-led firm has been shown to have a positive impact on female wages (Cardoso and Winter-Ebmer 2010; Bell 2005). ${ }^{2}$

In this paper, we contribute to this field by first evaluating the association between the gender of the immediate manager, that is, the manager to whom the employee reports working directly for, and wages for a representative sample of female employees, and second, by evaluating this association by manager position in the establishment hierarchy. Focusing on immediate managers, we can assess how manager gender matters at the level of management closest to the employee. Not only is the immediate manager presumably well informed about the employee's productivity or preferences but also if preferences, productivity enhancement, or influence on firm structure by manager gender play a role in management, these would arguably play a prominent role for the direct subordinate. More importantly, we differentiate between immediate managers at the highest level of an establishment (e.g., a CEO, small business owner, etc.) and managers being below this level of management. This is an important distinction because the impact of

\footnotetext{
${ }^{1}$ Studies addressing the gender wage gap also yields mixed evidence between female management representation either at the board-room, executive or management level (Abraham 2013; Cardoso and Winter-Ebmer 2010; Hensvik 2014; Abraham 2013; Srivastava and Sherman 2015; Bertrand et al., 2014; Hultin and Szulkin 2003).

${ }^{2}$ For a related strand of research assessing other outcomes such as profit, risk level and employment policies, see, e.g., Adams et al. (2011), Khan and Vieito (2013), Matsa and Miller (2013), Parrotta and Smith (2013), Bertrand et al. (2014), Gregory-Smith et al. (2014), Huffman et al. (2010) and Cohen and Broschak (2013).
} 
individual management may be different at different organizational levels. First, the influence of management on firm policies such as wage setting, promotions, and resource allocation to subordinates is presumably stronger at the highest level of management compared to lower levels. Second, the possibility of influencing the degree to which an organization is either female- or family-friendly is presumably higher at the highest level of management. Third, also within a given firm structure, a manager at the highest level would have a stronger influence over employee outcomes than a lower-level manager. We thus expect the degree of the beneficial impact of having a female manager on employee outcomes to be higher at a higher level of management, thus among managers with more decision-making power, than at a lower level of management.

Using a representative sample from matched employer-employee data based on cross-sectional survey data from the Swedish Level of Living Survey (LNU) 2010 linked to employer registry data, we show that having an immediate female manager instead of an immediate male manager is negatively associated with female employees' wages. However, dividing the sample by manager position, and thus presumably by the degree of manager influence on employee outcomes, we find a statistically significant heterogeneous association by manager position with a negative association among those with a lower-level manager and a tendency toward a positive association among those with a manager at the highest level of management. This result is robust not only to adjusting for male and female managers sorting into managing different employees or jobs, but also to employee sorting into male or female management on, e.g., working with differently remunerated work tasks within a job, in different firm sizes, employees' having different noncognitive traits or family commitments, and working in establishments with different gender compositions.

At first glance, our results are in line with earlier literature that find a negative association between female wages and working for a female as compared to male manager (Srivastava and Sherman 2015; Rothstein 1997). However, when we account for a large set of sorting patterns on employee and job traits, our point 
estimate of working directly for a female immediate manager at the highest level is positive (although insignificant) at $2.5 \%$ with a confidence interval between $-1.5 \%$ and $6.5 \%$. In contrast, when we study the association of working directly for a female manager in mid-level management, the association is negative at -5.1 $\%$ and statistically significant at the 1 percent level, with a confidence interval between $-1.2 \%$ to $-9 \%$. Thus, for the higher level managers our results support previous work finding a positive association from working either at a female-led firm (Cardoso and Winter-Ebmer 2011; Bell 2005) or in an establishment with a higher share of female managers (Hultin and Szulkin, 1999). Consequently, the analysis highlights the importance of considering management position.

The remainder of the paper is organized as follows. In the next section, the related literature is reviewed. In Section 3, we describe the data and provide descriptive statistics. Our regression results are reported in Section 4. Section 5 discusses our findings. Conclusions are provided in Section 6.

\section{Related literature}

In this section, we briefly review the literature on the relationship between female employees' wages and the gender of the manager, the gender composition of managers and the gender of the owner or highest-level executive.

Studies that similar to our study examine how working directly for a female as opposed to a male manager influences employee wages yield mixed evidence. Using longitudinal data from a firm within the information service industry between 20052009, Srivastava and Sherman (2015) show that switching from reporting to a male manager to a female manager yielded no change in the gender wage gap. Instead, some support is found that female employees attained a lower salary in the following year among those who switched from a male to a female manager compared to male employees that did the same switch. Using longitudinal within-job firm data from a large retail financial service firm between 1996-1999, Abraham (2013), however, shows that while the overall gender gap did not differ based on manager gender, the gender wage gap was lower among those with a female manager for subordinates in 
the lowest organizational ranks. Using US cross-sectional data from the National Longitudinal Survey of Youth (NLSY) of employees between 17-25 years of age Rothstein (1997) show that female wages were negatively correlated with having a female as compared to male manager, controlling for education, experience, tenure, race, and share of women in the occupation and industry.

The above studies are the most similar to ours yet differ in two important regards. First, while Srivastava and Sherman (2015) and Abraham (2013) have longitudinal data, our study is limited to cross-sectional data. However, our study is based on a representative sample of employer-employee matched data. Our study also differs from Rothstein (1997) as the NLSY data does not constitute a representative sample of the labor market at large because they only contain young employees. In addition, as also acknowledged by the author, the NLSY data allow accounting for a standard set of controls, leaving important sorting or selection patterns potentially unaccounted for. Second, we have direct information on managerial rank, thus allowing for a differentiation between managers at different levels of the firm's organizational hierarchy. ${ }^{3}$

Studies evaluating the association between female employees' wages and the share of female managers in the organization provide a positive or no association between female wages and share of female managers. Using Swedish cross-section data from the LNU 1991 and Swedish 1991 Establishment Survey, Hultin and Szulkin (1999) find a positive correlation between the share of female managers and female wages. More specifically, it is found that a female employee's wage is approximately 5 percent higher if she moves from an organization with only male

\footnotetext{
${ }^{3}$ Previous studies that consider the relationship between the gender of the immediate manager and outcomes other than the wage of female employees are e.g., Delfgaauw et al. (2013), Halldén (2015) and Giuliano et al. (2006). Delfgaauw et al. (2013) study a field experiment on sales competitions among Dutch retail stores and show that the gender of the manager had a direct impact on female productivity; female employees improve their performance more when working for a female manager. Using the LNU 2000 and matched employer register data, Halldén (2015) finds that for female employees in the private sector, the chances of receiving long initial on-thejob training are lower if the immediate supervisor is a woman. Using data from a large US retail firm, Giuliano et al. (2006) find that female employees are less likely to quit with a female store manager compared to with a male store manager, whereas dismissals and promotion rates did not differ by manager gender.
} 
managers to one with fifty percent female managers, and it is 10 percent higher if she moves to an organization with only female managers. Similarly, estimating separate fixed-effects models on Swedish employee-employer data from the private sector, Hensvik (2014) finds either no or a very small negative effect between female wages and the share of female managers when controlling for establishment and worker-fixed effects; if a female employee moves from an organization with only male managers to one with fifty percent female managers, her wage is approximately 0.05 percent lower, or 0.1 percent lower with a move to an organization with only female managers. Studying the private sector and using longitudinal Swedish wage data, NIER (2011) finds that the share of female managers within an industry has no association with female wages.

Studies addressing working in a male versus a female-led establishment provide evidence of a positive association between female wages and working in a femaleled establishment. Using Portuguese longitudinal data from 1987-2000, Cardoso and Winter-Ebmer (2010), find that females obtain higher wages in female-led firms; working in a female-led firm is associated with a 1-3 percent higher wage for female employees compared to male employees. Adding firm-fixed effects did not substantially change these estimates for the female employees. Using data from Standard and Poor's Execu Comp data for 1992-2003, Bell (2005) also estimates fixed-effects models with worker- and firm-fixed effects and finds that female executives earn approximately 10-20 percent more when they work in firms with a female CEO than in firms with a male CEO. ${ }^{4}$

\footnotetext{
${ }^{4}$ Related are studies on the gender wage gap and female management providing evidence of positive or no effects on the wage gap arising out of a larger representation of women among managers. Considering the share of female managers, Hirsch (2013), Cohen and Huffman (2007) and Hultin and Szulkin, (2003) find that the gender wage gap is lower when the share of female managers is higher, whereas Hensvik (2014) finds no such systematic relation. Cardoso and Winter-Ebmer (2010) and Bell (2005) find that the gender wage gap is lower in female-led firms, whereas Penner and Toro-Tulla (2010) find no such relationship. Bertrand et al. (2014) similarly observe no statistically significant relationship between the percentage of women on the board and the likelihood that a female employee is a top earner in the company.
} 


\section{Data}

We use a sample of matched employer-employee data from the Swedish Level of Living Survey (LNU) 2010, containing a random sample of approximately 4,400 observations drawn from the Swedish population between 18 and 75 years of age, which is matched with employer-registry data from the Longitudinal Integration Database for Health Insurance and Labor Market Studies (LISA). ${ }^{5}$ From these observations, we restrict the analysis to employees who can be matched with the employer registry data resulting in approximately 1700 observations. As there are too few observations on males with a female manager and in particular, male employees with a female manager at the highest level of management, we restrict the analysis to female employees resulting in 822 observations.

Our first variable of interest, the gender of the immediate manager, is derived from the answer to the question "Is your immediate manager a man or woman?" and if the manager is female, the dummy variable is equal to 1 , whereas it is 0 if the manager is male. The second variable of interest is the manager's position in the organization, derived from "Is your immediate manager the highest manager in the workplace?" If the respondent's answer is yes, we classify the manager as being in the highest management position, which we refer to as "high-level manager". If the answer is no, we classify the manager as a lower-level manager, whom we refer to as a "mid-level manager". Note that with these classifications of manager position, a high-level manager can be the highest manager in either a small or large establishment and thus, high-level managers can be either owners of small businesses or top managers or CEOs in large establishments. Similarly, the classification of a mid-level manager contains managers at a level of management second from the top and managers at the lowest level of management.

To estimate the association between wages and the gender of the immediate manager we use standard Mincer wage equations. As our dependent variable we use the natural logarithm of the gross hourly wage, which is a self-reported measure

\footnotetext{
${ }^{5}$ For a detailed description of the Swedish LNU 2010 and LISA, see Evertsson \& Magnusson (2014) and Statistics Sweden (2011).
} 
converted into the equivalent of the gross hourly wage (regardless of how it is reported). In all regressions, we include a standard subset of controls for employeespecific characteristics (years of education, labor market experience, labor market experience squared and tenure), establishment-specific characteristics (public or private sector, a dummy for establishment size over 100 employees, a dummy for working part-time and a continuous variable for job qualifications) and the share of women in the occupation. The variables are described in detail in Appendix Table 1.

Table 1 reports the descriptive statistics for the wage variable and the standard controls. The majority of the employees - 60 percent-have a female immediate manager, whereas 40 percent have a male immediate manager. Note that the large share of employees with a female immediate manager reflects the fact that we are analyzing only female employees who are more likely to work in female-dominated occupations in which the share of female managers is high. Moreover, because the data include immediate managers, we also capture lower-level managers, a position held by more female managers. Female employees with an immediate female manager (at either level of management) are less likely to work in the private sector, slightly less likely to work in larger establishments, more likely to work part-time and more likely to work in female-dominated occupations, compared to those who work for a male immediate manager. Female employees are also somewhat more likely to have a female manager if they have a lower-level manager (64 percent) compared to if they have a highest-level manager (55 percent). Female employees with an immediate manager at the highest level are more likely to work in smaller establishments compared to those who have an immediate mid-level manager. By construction, however, working directly for the highest-level manager is more likely the smaller the firm. ${ }^{6}$

\footnotetext{
${ }^{6}$ All of the results are robust to using a finer division of establishment size, both as a continuous variable from the employer-registry data on establishment size and from the LNU data on six categories $(1-9,10-19,20-49,50-99,100-499,500+)$ to which the respondent could report the number of employees at the workplace.
} 


\section{Results}

Table 2 reports the estimates of OLS regressions of the natural logarithm of the gross hourly wage adjusting for the standard controls. We show the coefficients only for key variables: the complete results are shown in the corresponding appendix tables. In the first column of panel A, we show the uncorrected differences between having a female versus a male manager without accounting for manager position. On average, female employees with a female manager have $8.3 \%$ lower wages than employees with a male manager. Dividing the sample by manager position, the estimates in panel A, columns 2 and 3, show that the uncorrected difference varies by manager position. Among employees with a manager at the highest level of management, female employees with a female manager have $4.3 \%$ lower wages than employees with a male manager, whereas for the equivalent employees with a lower-level manager, the difference is $12.4 \%$. If we control for employee-specific characteristics, the coefficient on having an immediate female manager changes to $4.8 \%$ among those with high-level managers and $11.6 \%$ among those with mid-level managers. Adjusting also for establishment-specific characteristics, the estimate for having a high-level manager is negative but no longer statistically significant among those having a high-level manager, whereas the estimate for mid-level managers is reduced to $7.3 \%$. When we adjust for female managers being more common in female-dominated occupations that are typically low-wage occupations, both estimates are further reduced, and remain negative, see columns 3 and 4 in panel B.

Without a division by manager position, the above provides suggestive evidence for an overall negative association between wages and working for a female immediate manager as opposed to a male immediate manager. Pooling the data, see column 5 in panel $\mathrm{B}$, it is found that the overall association between having a female versus a male immediate manager is $-3.6 \%$, suggesting that female employees with a female immediate manager earn a $3.6 \%$ lower wage than do similar female employees with a male immediate manager. Yet, note that many of the 
coefficients for the control variables differed across managerial position such as education, tenure, public sector, establishment size and female share in the occupation, reflecting that employees with an immediate male or female manager in different management positions are found in diverse types of establishments and work.

One concern with cross-section data is the difficulty of separating the influence of the manager's gender from other factors that could generate wage differentials such as unobserved differences in productivity or sorting on work tasks that are related to the gender of the manager, thus biasing the OLS estimate. Typically, it would be preferable with panel data to account for such unobserved employeeor establishment-fixed effects. The data from the LNU 2010, however, contain unusually detailed information about other characteristics that could presumably be related to sorting patterns by manager gender and the manager's position in the establishment. In particular, we focus on accounting for sorting patterns of female employees and manager gender based on differences in family commitment, noncognitive traits or more precisely, psychological traits and attitudes toward work, work tasks and sorting into establishments with a higher or lower share of female employees. In addition, this allows us to assess how much these often unobserved variables add to our understanding of wage differences accounted for by manager gender.

\subsection{Noncognitive traits and family commitment}

The first bias we address arises from the possibility that male and female managers may encounter employees with different types of personality traits, work attitudes or family commitments and that this sorting would differ by manager position. That is, the negative association of wages and having a female immediate manager might be driven by an unmeasured ability or productivity selection, implying that some organizations or, in particular, male managers would attract female workers with an especially high productive capacity. To adjust for this unmeasured bias in worker productivity, we control for differences in noncognitive traits among em- 
ployees. Allowing us to control for sorting on noncognitive traits may be important as both Mueller and Plug (2006) and Bertrand (2011) find that they are significant for explaining wage differentials. Moreover, Gill and Prouse (2015) show that personality affects performance and learning. In particular, more agreeable and emotionally stable individuals perform better and learn faster. The differences in noncognitive traits are first assessed from differences in the Big Five personality traits, commonly denoted as OCEAN, which describe an individual's degree of openness, conscientiousness, extroversion, agreeableness, and neuroticism. A thorough description of the personality traits is given in Appendix Table 3. Openness is measured by the degree to which the respondent has "an active imagination and artistic interest". Conscientiousness is measured by the degree to which the respondent "tends not to be lazy and does things thoroughly". Extroversion is measured by the degree to which the respondent is "outgoing and social". Agreeableness is measured by the degree to which the respondent "trusts others and do not find faults in others". Finally, neuroticism is measured by the degree to which the respondent "does not handle stress well or easily becomes nervous". All of the variables are converted into dummy variables; see more in Table 3 of the Appendix.

Differences in noncognitive traits are next assessed from three measures of attitudes toward work: the willingness to lead, the willingness to exert effort or perseverance, and work commitment. The willingness to lead is measured by the degree to which the respondent agrees to the statement "I am a natural leader". The willingness to persevere, or to exert effort, is measured with the degree to which the respondent agrees to statements such as "I do not give up when encountering a setback", "I tend to get things done easily", and "I always finish what I start". Work commitment is measured by the respondents' answer to "If you did not need the wage, how much would you work?", where being work committed is replying that you would work 1 or more hours per week.

Raw mean wages differ for respondents classified above or below the cutoff value of the noncognitive traits, see Table 3. In particular, mean wages are lower 
for employees who are classified as neurotic and higher for those who are classified as extroverted and agreeable. Employees who are classified as more willing to lead, more willing to exert effort or are committed to work also have higher mean wages.

The employees' noncognitive traits also differ along manager gender and position, see Table 4. Employees with a female immediate manager are more likely to be conscientious and neurotic, two noncognitive traits that are associated with lower mean wages, compared to employees with a male immediate manager. In particular, employees working for a high level female manager are less likely to be defined as open and extroverted, two personality traits associated with higher pay. Employees with a female immediate manager are, on the other hand, slightly more willing to exert effort compared to employees with a male immediate manager while there is no significant difference in willingness to lead or work commitment.

Table 5, panel A, columns 1 to 4 present the regression results (see Appendix Table 5 for complete results). Although the coefficients on the noncognitive traits such as being open, being willing to lead and being willing to exert effort differ by the manager's position: the negative association between wages and having a female manager versus a male manager, is only explained to a small extent by differences in noncognitive traits at both levels of management. Overall, the coefficient for having a female manager is negative and statistically significant at the 1 percent level at the lower level of management, and it is negative and insignificant at the highest level.

The negative association between wages and having a female immediate manager could also be due to female managers possibly employing more female-friendly work practices and thereby attracting employees with higher family commitments compared to male managers. In particular, this factor would be important among employees with a high-level manager, presuming that such managers have a greater ability to influence work practices. Measuring family commitments by being married (or cohabitating), number of children and having small children, the descriptive statistics in Table 4, however, show no support for such sorting because there is no difference in family commitments by manager gender, apart from high imme- 
diate male managers having a larger share of female employees with small children. For a variable description, see Appendix Table 4. The estimates in Table 5, panel A, columns 5 and 6 , show no indication of a difference in family commitment between employees working for a male or female immediate manager being important in explaining the lack of wage differences among employees working for a high- or mid-level immediate managers.

\subsection{Work tasks}

The second bias we address comes from the possibility of an unmeasured selection of employees or managers into work tasks that are differently rewarded. If female managers are more likely than male managers to supervise low-paid tasks, the OLS estimate on having a female immediate manager would be negatively biased. This bias could also be different depending upon managerial position. To explore worktask assignment, we exploit several questions in the LNU 2010. The work tasks are as follows: (i) "work with people (nonmanagerial)," based on the question, "How much of your working time is spent working with customers, patients, pupils or other people who are not other personnel?"; (ii) "emotionally demanding work," based on the question, "How much of your working time is spent on emotionally demanding tasks?"; (iii) "managerial work," based on the question, "How much of your working time involves managing other employees' work, such as steering, instructing, coordinating or similar?"; (iv) "work with text/numbers," based on the question, "How much of your working time is spent working with text and or numbers, i.e., writing, counting, reading, editing or similar?"; and (v) "manual work," based on the question, "How much of your working time is spent working with items or other materials, such as manufacturing, building, preparing, cleaning, repairing, packing, transporting or similar tasks?" The variables "work with people" and "work with text/digits" take the value of 1 if the respondent works on these tasks all or almost all of the time, whereas the variables for "emotionally demanding work," "managerial work" and "manual work" take the value 1 if the respondent works with these tasks at least some of the time (these cutoff values 
are chosen because few respondents work with these latter tasks always or almost always). For a detailed variable description, see Appendix Table 4.

The raw mean wages varies considerably by work task as reported in Table 3. Wages are higher for employees who work with managerial tasks, texts and numbers, whereas wages are lower for employees who either work with people or do manual work. There are also considerable mean differences in the employees' work tasks both along manager gender and manager position; see the descriptive statistics in Table 4. Employees with a female manager work almost always or always to a larger extent with lower-paid tasks such as "work with people" or "manual work" compared to employees with a male manager. The reverse holds for working with text and numbers. Employees with a female manager also work more often with emotionally demanding tasks, at least some of the time. This indicates that the negative association found previously may be due to sorting on work tasks. The differences by manager gender in work tasks are greater among managers at the highest level of management for managing highly paid tasks such as managerial work and low-paid tasks such as working with people. The difference between employees with a male or female manager and work tasks is greater among those with a manager in a mid-level management position for working with texts and numbers and in manual work. ${ }^{7}$

Table 5, panel B, columns 1 and 2 present the results adjusting for female and male managers managing differently remunerated work tasks. First, controlling for work tasks is shown to be important in explaining wage differences across the female employees because the adjusted R-squared increases in both groups, especially among those with a high-level manager. Second, and importantly, accounting for

\footnotetext{
${ }^{7}$ Another concern that we address is whether the negative association between wages and working for a female manager is because male and female managers differ with respect to the number of subordinates that they manage. If female managers supervise a larger number of subordinates than male managers would, the possibility of influencing each employee would be lower with a female manager than a male manager. To assess the number of subordinates, we use a survey question about the immediate manager having either 1-19, 20-49 or 50 or more subordinates. Adjusting for employees with female managers more often working for a manager with a larger number of subordinates, compared to employees with a male manager, our estimates are essentially unchanged.
} 
female managers being overrepresented among those managing low-paid tasks, the point estimate for having a female immediate manager at the highest level changes and becomes positive, although not statistically significant. The point estimate for working for a lower-level manager is robust to the inclusion of work task, but is lowered to $-5.5 \%$.

\subsection{Gender composition of the establishment}

A third bias we address is the influence of gender composition of the employees in the establishment. If, compared to male immediate managers, female immediate managers are more often situated in female-dominated establishments, the OLS coefficient would be negatively biased if female-dominated establishments either are less profitable on average or more often are low-wage firms. To adjust for the gender composition of the establishment, we use the establishment data with information about the share of women in each establishment. For a detailed variable description see Appendix Table 4.

To evaluate whether raw mean wages differ by share of women in the establishment we use three cutoff values for the share of women in the establishment, see Table $3{ }^{8}$ These suggest that the larger the share of women in the establishment, the lower the mean wage. Table 4 further reports how employees with a female manager are also more likely to work among a larger share of women in the establishment, with a slightly larger difference among the employees with a lower-level manager. The regression results presented in Table 5, panel B, columns 3 and 4 show that the negative association between having a female manager is robust to accounting for the female domination of a establishment at the middle-management level. Again, the point estimate for having a female immediate manager at the highest level of management changes and becomes positive when we account for female managers in this position being overrepresented in establishments with a large share of women.

\footnotetext{
${ }^{8}$ We have also run regressions with three dummy variables indicating the share of women in the establishment: $0-0.3,0.31-0.69$, and $\geq 0.70$. The results are unchanged and thus robust to this specification.
} 


\section{Discussion}

Taken together, our analysis highlights the importance of accounting for manager position as the association between wages of female employees and the gender of the immediate manager is heterogeneous between managers at different levels of management. Accounting for all observable differences the female manager coefficients are statistically significantly different below the 1 percent level of significance between managers at the highest versus the middle level of management. ${ }^{9}$ On the contrary, not accounting for differences in manager position, the overall association on female wages of working directly for a female manager is negative or even insignificantly different from zero (see Appendix Table 5C). The analysis further highlights the importance of accounting for sorting of managers and employees as having a female manager as opposed to a male manager is associated with employees having more low-paid noncognitive traits and job characteristics. ${ }^{10}$ Comparing the point estimate for female managers at the highest level when only using the standard controls (Table 2, panel B, columns 3 and 4) to that when using all controls, the result changes from $-0.1 \%$ to $+2.5 \%$ (a statistically significant change at the 10 percent level). Thus, the association between wages and having a female manager changed in a positive direction when accounting for all controls. Surprisingly, the coefficient for a female immediate middle manager is rather stable at approximately -5-6\% and robust to all controls for sorting. Importantly, this difference in the female coefficients between the highest and middle levels of management is also statistically significant at the 10 percent level when controlling for standard controls, but is estimated more precisely at the 1 percent level of significance with all controls. ${ }^{11}$

\footnotetext{
${ }^{9}$ This is tested using a SUEST test in Stata in which the equality of the female manager coefficients between managers' positions is tested following the estimates provided in Table 5 columns 5 and 6 in panel B.

${ }^{10}$ The results of a negative coefficient on having a female manager among those with a lowerlevel manager and a statistically different association by manager position are robust to the inclusion of industry and occupation.

${ }^{11}$ Again, we test this by using SUEST tests in Stata, comparing differences between tests using all controls to those using standard controls (Table 2, panel B).
} 
Although our analysis does not allow for any differentiation between mechanisms explaining the heterogeneous association, we provide a discussion on potential explanations below.

The literature contains several arguments for why one could expect a positive association between female wages and having a female manager. Among those are female employees possibly benefiting from having a female manager through more efficient mentoring, or female managers enhancing female employees' productivity through being better at assessing female employees' specific qualifications and thereby being better at productively managing female employees, or that female employees are more willing to or better at negotiating their wage with a female manager than with a male manager. In addition, female employees may benefit from having a female manager if male managers have a tendency to discriminate against female subordinates. The results of our study, however, find no support for these arguments in terms of wage outcomes for the female employees at lower levels of management.

The negative association at the middle level would, however, be compatible with an argument for compensating wage differentials if female managers provide better work environments or attributes. In line with the literature suggesting that females seem to react less than males to competitive incentives (Bertrand 2011), it might also be that female managers choose different schemes, less based on monetary rewards to incentivize, than do male mid-level managers. Moreover, despite the rich set of controls used, there could be an omitted variable bias in that either female employees working for a female mid-level manager have less productive characteristic than those working for a male mid-level manager, or that female employees with female managers could be overrepresented within lowwage organizations and that was not accounted for by female domination of an establishment, female domination of an occupation, or firm size. However, note that all of these arguments beg the answer to the question of why this should hold only at the middle level but not at the highest level of management.

Finally, an argument that would be consistent with our finding of a hetero- 
geneous association by manager position could be a difference in the degree of decision-making power if female managers at lower levels of the establishment hierarchy would be less able to bargain or obtain resources for their employees compared to male managers at the same level. In addition, when not at the highest level of the establishment, female managers may be less able to influence firm practices in a more female-friendly manner that could enhance female employees' productivity. Consequently, if female managers influence outcomes to a lower degree than male managers do at lower levels of management, we would attain a negative estimate among these managers, while not among those managers with a high degree of decision-making power.

\section{Conclusions}

This paper provides a first attempt to study the association between wages of female employees who work directly for a female as opposed to male manager using a representative sample and with a differentiation of the analysis by manager position. In contrast to the expectation commonly advanced in the public-policy debate of female managers being particularly able to enhance female productivity, we find a negative association between female management and the wages of their female subordinates. However, adjusting for sorting of employees by manger gender on in particular work tasks and female domination of the establishment, we find this pattern only among subordinates who work for a lower-level manager, not among those working for a manager at the pinnacle of the establishment, thus presumably capturing a difference in manager influence on employee outcomes. The analysis thus highlights the importance of assessing the association of the gender of the immediate manager at different levels of management and the importance of accounting for sorting managers and employees because female employees who have an immediate female manager are more likely to have more low-paid noncognitive traits and job characteristics compared to employees with a male manager. 


\section{$7 \quad$ References}

Abraham, Mabel. 2013. "Does Having Women in Positions of Power Reduce Gender Inequality in Organizations? A Direct Test." MIT Working Paper.

Adams, Renee, Stephen, Gray and John Nowland. 2011. "Does Gender Matter in the Boardroom? Evidence from the Market Reaction to Mandatory New Director Announcements." SSRN Working Papers.

Akerlof, George A. and Rachel. E. Kranton. 2000. "Economics and Identity." The Quarterly Journal of Economics, Vol. 115, No. 3, pp. 715-753.

Athey, Susan C., Christopher Avery and Peter Zemsky. 2000. "Mentoring and Diversity." American Economic Review, Vol. 90, No. 4, pp. 765-786.

Becker, Gary. S. 1971. The Economics of Discrimination. Chicago: The University of Chicago Press.

Bell, Linda A. 2005. "Women-Led Firms and the Gender Gap in Top Executive Jobs.", IZA Discussion paper No. 1689.

Bertrand, Marianne. 2011. "New Perspectives on Gender." In O. Ashenfelter and D. Card eds, Handbook of Labor Economics, chapter 17, Vol. 4B, Amsterdam, The Netherlands: Elsevier B.V, pp. 1545-1592.

Bertrand, Marianne, Sandra E. Black, Sissel Jensen and Adriana Lleras-Muney. 2014. "Breaking the Glass Ceiling? The effect of Board Quotas on Female Labor Market Outcomes in Norway." IZA Discussion paper No. 8266.

Brown-Johnson, Nancy and Terri A. Scandura. 1994. "The Effect of Mentorship and Sex-role Style on Male-Female Earnings", Industrial Relations: A Journal of Economy and Society, Vol. 33, No. 2, pp. 263-274.

Cardoso, Ana Rute and Rudolf Winter-Ebmer. 2010. "Female-led Firms and Gender Wage Policies." Industrial and Labor Relations Review, Vol. 64, No. 1, pp. 143-63. Cohen, Lisa E. and Joseph. P. Broschak. 2013. "Whose Jobs Are These? The Impact of the Porportion of Female Managers on the Number of New Management Jobs Filled by Women versus Men." Administrative Science Quarterly, Vol.58, No. 4, pp. 509-541. 
Cohen, Philip N. and Matt L. Huffman. 2007. "Working for the Woman? Female Managers and the Gender Wage Gap." American Sociological Review, Vol. 72, No. 5, pp. 681-704.

Delfgaauw, Josse, Robert Dur, Joeri Sol and Willem Verbeke. 2013. "Tournament Incentives in the Field: Gender Differences in The Workplace." Journal of Labor Economics, Vol. 32, No. 2, pp. 305-326.

Evertsson, Marie and Charlotta Magnusson. 2014. Dimensions of Inequality. Childhood Conditions, Work and Health in Sweden. Stockholm: Liber.

Gill, David and Victoria Prouse. 2015. "Cognitive Ability, Character Skills, and Learning to Play Equilibrium: A Level-k Analysis. Journal of Political Economy." forthcoming.

Giuliano, Laura, Levine, David I. and Jonathan Leonard. 2006. "Do Race, Age, and Gender Differences Affect Manager-Employee Relations? An Analysis of Quits, Dismissals, and Promotions at a Large Retail Firm." IRLE Working Paper, No 151-07.

Gregory-Smith, Ian, Brian G.M. Main and Charles A. O'Reilly. 2014. "Appointments, Pay and Performance in UK Boardrooms by Gender." Economic Journal, Vol. 124, No. 2, pp. F109-F128.

Halldén, Karin. 2015. "Taking Training to Task: Sex of the Immediate Manager and Men's and Women's Time in Initial On-the-Job Training. Work 8 Occupations, forthcoming.

Hensvik, Lena. 2014. "Manager impartiality: Worker-firm matching and the gender wage gap." Industrial and Labor Relations Review, Vol. 67, No. 2, pp. 395-421.

Hirsch, Boris. 2013. "The impact of female managers on the gender pay gap: Evidence from linked employer-employee data for Germany." Economics Letters, Vol 119, pp. 348-350.

Hultin, Mia and Ryszard Szulkin. 1999. "Wages and Unequal Access to Organizational Power: An Empirical Test of Gender Discrimination." Administrative Science Quarterly, Vol. 44, No. 3, pp. 453-472.

Huffman, Matt L., Cohen, Philip N. and Jessica Pearlman. 2010. "Engendering 
Change: Organizational Dynamics and Workplace Gender Desegregation, 19752005." Administrative Science Quarterly, Vol. 55, pp. 255-277.

Hultin, Mia and Ryszard Szulkin. 2003. "Mechanisms of Inequality, Unequal Access to Organizational Power and the Gender Wage Gap." European Sociological Review, Vol. 19, No 2, pp. 143-159.

Jackson, Matthew. 2010. "An Overview of Social Networks and Economic Applications." in eds. J. Benhabib, A. Bisin, and M.O. Jackson, The Handbook of Social Economics, Elsevier Press, pp. 511-586.

Khan Walayet A. and João Paulo Vieito. 2013. "CEO Gender and Firm Performance." Journal of Economics and Business, Vol. 67, May-June, pp. 55-66.

NIER. 2011. The Report on Wage Formation 2011. National Institute of Economic Research, Stockholm.

Matsa, David A. and Amalia R. Miller. 2013. "A Female Style in Corporate Leadership? Evidence from Quotas." American Economic Journal: Applied Economics, Vol. 5, No. 3, pp. 136-169.

McPherson, Miller, Lynn Smith-Lovin and James M. Cook. 2001. "Birds of a Feather: Homophily in Social Networks." Annual Review of Sociology, Vol. 27, pp. 415-444.

Mueller, Gerrit and Erik J.S. Plug. 2006. "Estimating the Effect of Personality on Male and Female Earnings." Industrial and Labor Relations Review, Vol. 60, No.1. pp. 3-22.

Parrotta, Pierpaolo and Nina Smith. 2013. "Female-Led firms: Performance and Risk Attitudes." IZA Discussion Paper No. 7613.

Penner, Andrew M. and Harold. J. Toro-Tulla. 2010. "Women in Power and Gender Wage Inequality: The Case of Small Businesses." in Christine L. Williams, Kirsten Dellinger (ed.) Gender and Sexuality in the Workplace, Research in the Sociology of Work, Emerald Group Publishing Limited, Vol. 20, pp. 83-105.

Rosén, Åsa. 2003. "Search, Bargaining and Employer Discrimination." Journal of Labor Economics, Vol. 21, No. 4. pp. 807-829.

Rothstein, Donna S. 1997. "Early Career Supervisor Gender and the Labor Market 
Outcomes of Young Workers." in Blau, F. D. \& Ehrenberg, R. G. (eds.), Gender and Family Issues in the Workplace. New York: Russell Sage. pp. 210-255.

Srivastava, Sameer B. and Eliot L. Sherman. 2015. "Agents of Change or Cogs in the Machine? Rexamining the Influence of Female Managers on the Gender Wage Gap." American Journal of Sociology, Vol. 120, No.6. pp. 1778-1808.

Statistics Sweden (SCB). 2011. "Background Facts, Labour and Education Statistics", Integrated database for labour market research, Stockholm: Statistics Sweden. 


\begin{tabular}{|c|c|c|c|c|}
\hline \multirow[b]{3}{*}{ Variables } & \multirow{2}{*}{\multicolumn{2}{|c|}{$\frac{\text { Employees with a male manager }}{40 \%}$}} & \multirow{2}{*}{\multicolumn{2}{|c|}{$\frac{\text { Employees with a female manager }}{60 \%}$}} \\
\hline & & & & \\
\hline & $\begin{array}{l}\text { High-level } \\
\text { male manager }\end{array}$ & $\begin{array}{l}\text { Mid-level } \\
\text { male } \\
\text { manager }\end{array}$ & $\begin{array}{l}\text { High-level } \\
\text { female } \\
\text { manager }\end{array}$ & $\begin{array}{c}\text { Mid-level } \\
\text { female manager }\end{array}$ \\
\hline Share & 0.45 & 0.36 & 0.55 & 0.64 \\
\hline Hourly wage (SEK) & $\begin{array}{c}155.6^{* *} \\
(60.2)\end{array}$ & $\begin{array}{l}172.9 * * * \\
(50.8)\end{array}$ & $\begin{array}{c}145.3 * * \\
(40.0)\end{array}$ & $\begin{array}{c}151.2 * * * \\
(38.1)\end{array}$ \\
\hline \multicolumn{5}{|l|}{$\begin{array}{l}\text { Employee-specific } \\
\text { characteristics }\end{array}$} \\
\hline Years of education & 14.1 & 14.3 & 13.9 & 14.1 \\
\hline Years of labor market exp. & 20.4 & 20.6 & 21.7 & 20.6 \\
\hline Years of tenure & 10.2 & 10.3 & 12.0 & 11.1 \\
\hline \multicolumn{5}{|l|}{$\begin{array}{l}\text { Establishment-specific } \\
\text { character. }\end{array}$} \\
\hline Share in public sector & $0.41 * * *$ & $0.40^{* * *}$ & $0.61 * * *$ & $0.66^{* * *}$ \\
\hline $\begin{array}{l}\text { Share in establ. }>100 \\
\text { employees }\end{array}$ & $0.17 * *$ & $0.51 *$ & $0.11^{* *}$ & $0.44 *$ \\
\hline Share working part-time & $0.31 * *$ & $0.19 * * *$ & $0.40 * *$ & $0.35^{* * *}$ \\
\hline Job qualifications & 3.6 & 4.0 & 3.7 & 3.9 \\
\hline $\begin{array}{l}\text { Share of women in } \\
\text { occupation }\end{array}$ & $0.57 * * *$ & $0.50 * * *$ & $0.72 * * *$ & $0.69^{* * *}$ \\
\hline Observations & 150 & 176 & 186 & 310 \\
\hline \multicolumn{5}{|c|}{$\begin{array}{l}\text { Note: Standard deviations in parentheses. "High-level manager" refers to the manager being the highest manager in } \\
\text { the establishment, whereas "mid-level manager" refers to the manager not being the highest manager in the } \\
\text { establishment. For a detailed variable description, see Appendix Table } 1 \text {. } \\
\text { *Statistically significant mean difference by manager position and gender at the } .10 \text { level; ** Statistically significant } \\
\text { mean difference by manager position and gender at the } .05 \text { level; *** at the } .01 \text { level. } \\
\text { Source: Swedish Level of Living Survey } 2010 \text {. }\end{array}$} \\
\hline
\end{tabular}


TABLE 2 WAGE REGRESSIONS, ADDING STANDARD CONTROLS

A.

female manager

controls for employee-specific characteristics

controls for establishment -specific character. controls for share of women in occupation Constant

Adj. $R^{2}$

F-statistic

Observations

B.

female manager

controls for employee-specific characteristics controls for establishment-specific character. controls for share of women in occupation

Constant

Adj. $\mathrm{R}^{2}$

F-statistic

Observations

\begin{tabular}{ccccc} 
All & $\begin{array}{c}\text { High-level } \\
\text { manager }\end{array}$ & $\begin{array}{c}\text { Mid-level } \\
\text { manager }\end{array}$ & $\begin{array}{c}\text { High-level } \\
\text { manager }\end{array}$ & $\begin{array}{c}\text { Mid-level } \\
\text { manager }\end{array}$ \\
\hline$-0.083^{* * *}$ & -0.043 & $-0.124 * * *$ & $-0.048^{*}$ & $-0.116^{* * * *}$ \\
$(0.018)$ & $(0.029)$ & $(0.023)$ & $(0.026)$ & $(0.020)$ \\
& & & $\mathrm{X}$ & $\mathrm{X}$ \\
& & & & \\
$5.059 * * *$ & $4.994 * * *$ & $5.115 * * *$ & $4.322 * * *$ & $4.410^{* * *}$ \\
$(0.014)$ & $(0.022)$ & $(0.018)$ & $(0.080)$ & $(0.060)$ \\
0.023 & 0.004 & 0.055 & 0.206 & 0.281 \\
20.753 & 2.186 & 29.169 & 18.367 & 38.980 \\
822 & 336 & 486 & 336 & 486
\end{tabular}

High-level Mid-level High-level Mid-level

\begin{tabular}{ccccc} 
manager & manager & manager & manager & All \\
\hline-0.025 & $-0.073^{* * *}$ & -0.010 & $-0.061^{* * *}$ & $-0.036^{* *}$ \\
$(0.025)$ & $(0.018)$ & $(0.026)$ & $(0.019)$ & $(0.015)$ \\
$\mathrm{X}$ & $\mathrm{X}$ & $\mathrm{X}$ & $\mathrm{X}$ & $\mathrm{X}$ \\
$\mathrm{X}$ & $\mathrm{X}$ & $\mathrm{X}$ & $\mathrm{X}$ & $\mathrm{X}$ \\
& & $\mathrm{X}$ & $\mathrm{X}$ & $\mathrm{X}$ \\
$4.593^{* * *}$ & $4.540^{* * *}$ & $4.703^{* * *}$ & $4.571^{* * *}$ & $4.594^{* * *}$ \\
$(0.086)$ & $(0.057)$ & $(0.097)$ & $(0.058)$ & $(0.050)$ \\
0.328 & 0.451 & 0.338 & 0.456 & 0.401 \\
19.164 & 45.270 & 18.066 & 41.668 & 55.929 \\
336 & 486 & 336 & 486 & 822 \\
\hline
\end{tabular}

Note: Standard errors are in parentheses. "High-level manager" refers to the manager being the highest manager in the establishment, whereas "mid-level manager" refers to the manager not being the highest manager in the establishment. Employee-specific controls are education (years), labor market experience (years), labor market experience squared and tenure (years). Establishment-specific controls are public sector, firm size above 100 employees, working part-time and job qualifications. Detailed variable description is given in Appendix Table 1. Complete results are shown in Appendix Table 2.

* Statistically significant at the .10 level; ** at the .05 level; *** at the .01 level.

Source: Swedish Level of Living Survey, 2010. 
TABLE 3. RAW MEAN WAGES FOR THE NONCOGNITIVE TRAITS, FAMILY VARIABLES, WORK TASKS AND GENDER COMPOSITION OF THE ESTABLISHMENT

\begin{tabular}{|c|c|c|}
\hline \multirow[b]{2}{*}{ Variables } & \multicolumn{2}{|c|}{ Variable } \\
\hline & $=1$ & $=0$ \\
\hline \multicolumn{3}{|l|}{ Noncognitive traits: $O C E A N$} \\
\hline Openness & 155.6 & 153.6 \\
\hline Conscientiousness & $157.5 * *$ & $151.4 * *$ \\
\hline Extroversion & $159.4 * * *$ & $150.3 * * *$ \\
\hline Agreeableness & 157.0 & 153.7 \\
\hline Neuroticism & $147.0 * * *$ & $157.2 * * *$ \\
\hline \multicolumn{3}{|l|}{ Noncognitive traits: work attitudes } \\
\hline Willingness to lead & $166.6 * * *$ & $149.1 * * *$ \\
\hline Willingness to preserve/exert effort & $159.8 * * *$ & $148.7 * * *$ \\
\hline Work commitment & $157.2 * * *$ & $145.4 * * *$ \\
\hline \multicolumn{3}{|l|}{ Family variables } \\
\hline Married or cohabiting & $157.4 * *$ & $149.7 * *$ \\
\hline No child & $149.1 * * *$ & $160.7 * * *$ \\
\hline 1 child & 158.4 & 154.7 \\
\hline 2 children or more & $161.7 * * *$ & $151.6^{* * *}$ \\
\hline Small children dummy & 158.0 & 154.6 \\
\hline \multicolumn{3}{|l|}{ Work tasks } \\
\hline Work with people (nonmanagerial) & $140.2 * * *$ & $165.1 * * *$ \\
\hline Emotionally demanding work & 156.3 & 154.8 \\
\hline Managerial work & $173.8 * * *$ & $142.4 * * *$ \\
\hline Work with text/digits & $164.7 * * *$ & $151.8 * * *$ \\
\hline Manual work & $136.1 * * *$ & $167.0 * * *$ \\
\hline \multicolumn{3}{|l|}{ Gender composition of the establishment } \\
\hline Share of women in the establishment: $\leq 0.30$ & $184.3 * * *$ & $157.5 * * *$ \\
\hline Share of women in the establishment: $0.31-0.69$ & $184.3 * * *$ & $149.0 * * *$ \\
\hline Share of women in the establishment: $\geq 0.70$ & $149.0 * * *$ & $157.5 * * *$ \\
\hline
\end{tabular}

Note: Standard deviations in parentheses. For a detailed variable description and cut-off values, see Appendix Table 3 and Appendix Table 4.

* Statistically significant mean difference at the .10 level; ** at the .05 level; *** at the .01 level.

Source: Swedish Level of Living Survey 2010. 
TABLE 4. DESCRIPTIVE STATISTICS OF THE NONCOGNITIVE TRAITS, FAMILY VARIABLES, WORK TASKS AND GENDER COMPOSITION OF THE ESTABLISHMENT

\begin{tabular}{|c|c|c|c|c|}
\hline Variables & $\begin{array}{c}\text { High-level } \\
\text { male } \\
\text { manager }\end{array}$ & $\begin{array}{l}\text { High-level } \\
\text { female } \\
\text { manager }\end{array}$ & $\begin{array}{c}\text { Mid-level } \\
\text { male } \\
\text { manager }\end{array}$ & $\begin{array}{l}\text { Mid-level } \\
\text { female } \\
\text { manager }\end{array}$ \\
\hline \multicolumn{5}{|l|}{ Noncognitive traits: $O C E A N$} \\
\hline Openness & 0.88 & 0.83 & 0.87 & 0.86 \\
\hline Conscientiousness & 0.59 & 0.64 & $0.64 *$ & $0.69 *$ \\
\hline Extroversion & $0.62 * *$ & $0.52 * *$ & 0.53 & 0.56 \\
\hline Agreeableness & 0.56 & 0.55 & 0.47 & 0.47 \\
\hline Neuroticism & 0.16 & 0.21 & 0.15 & 0.20 \\
\hline \multicolumn{5}{|l|}{ Noncognitive traits: work attitudes } \\
\hline Willingness to lead & 0.39 & 0.40 & 0.32 & 0.32 \\
\hline Willingness to persevere/effort & $0.55^{*}$ & $0.63 *$ & 0.60 & 0.61 \\
\hline Work commitment & 0.84 & 0.83 & 0.85 & 0.83 \\
\hline \multicolumn{5}{|l|}{ Family variables } \\
\hline Married or cohabiting & 0.71 & 0.70 & $0.78 *$ & $0.72 *$ \\
\hline No of children in household & 0.97 & 0.90 & 1.2 & 1.1 \\
\hline Small children dummy & $0.25 * *$ & $0.17 * *$ & 0.24 & 0.22 \\
\hline \multicolumn{5}{|l|}{ Work tasks } \\
\hline Work with people (nonmanagerial) & $0.33 * * *$ & $0.61 * * *$ & $0.18 * * *$ & $0.41 * * *$ \\
\hline Emotionally demanding work & $0.55 * * *$ & $0.75 * * *$ & $0.42 * * *$ & $0.64 * * *$ \\
\hline Managerial work & $0.45 * *$ & $0.33 * *$ & $0.48 *$ & $0.41^{*}$ \\
\hline Work with text/digits & 0.27 & 0.24 & $0.38 * * *$ & $0.24 * * *$ \\
\hline Manual work & 0.41 & 0.44 & $0.27 * * *$ & $0.38 * * *$ \\
\hline \multicolumn{5}{|l|}{ Gender composition of the establishment } \\
\hline Share of women in the establishment & $0.61 * * *$ & $0.78 * * *$ & $0.51 * * *$ & $0.70 * * *$ \\
\hline Observations & 150 & 186 & 176 & 310 \\
\hline \multicolumn{5}{|c|}{$\begin{array}{l}\text { Note: "High-level manager" refers to the manager being the highest manager in the establishment, whereas "mid- } \\
\text { level manager" refers to the manager not being the highest manager in the establishment. For a detailed variable } \\
\text { description, see Appendix Table } 3 \text { and Appendix Table } 4 \text {. } \\
\text { * Statistically significant mean difference by manager position and gender at the } .10 \text { level; ** at the .05 level; *** } \\
\text { at the . } 01 \text { level. } \\
\text { Source: Swedish Level of Living Survey, } 2010 \text {. }\end{array}$} \\
\hline
\end{tabular}


TABLE 5. WAGE REGRESSIONS, ADDING CONTROLS FOR THE NONCOGNITIVE TRAITS, FAMILY VARIABLES, WORK TASK AND GENDER COMPOSITION OF THE ESTABLISHMENT

\begin{tabular}{|c|c|c|c|c|c|c|}
\hline A. & $\begin{array}{l}\text { High-level } \\
\text { manager }\end{array}$ & $\begin{array}{l}\text { Mid-level } \\
\text { manager }\end{array}$ & $\begin{array}{l}\text { High-level } \\
\text { manager }\end{array}$ & $\begin{array}{l}\text { Mid-level } \\
\text { manager }\end{array}$ & $\begin{array}{l}\text { High-level } \\
\text { manager }\end{array}$ & $\begin{array}{c}\text { Mid-level } \\
\text { manager }\end{array}$ \\
\hline female manager & $\begin{array}{l}-0.009 \\
(0.026)\end{array}$ & $\begin{array}{l}-0.062 * * * \\
(0.019)\end{array}$ & $\begin{array}{l}-0.019 \\
(0.026)\end{array}$ & $\begin{array}{l}-0.066^{* * * *} \\
(0.019)\end{array}$ & $\begin{array}{l}-0.009 \\
(0.026)\end{array}$ & $\begin{array}{c}-0.057 * * * \\
(0.019)\end{array}$ \\
\hline controls for employee-specific characteristics & $\mathrm{X}$ & $\mathrm{X}$ & $\mathrm{X}$ & $\mathrm{X}$ & $\mathrm{X}$ & $\mathrm{X}$ \\
\hline controls for establishment -specific character. & $\mathrm{X}$ & $\mathrm{X}$ & $\mathrm{X}$ & $\mathrm{X}$ & $\mathrm{X}$ & $\mathrm{X}$ \\
\hline control for share of women in occupation & $\mathrm{X}$ & $\mathrm{X}$ & $\mathrm{X}$ & $\mathrm{X}$ & $\mathrm{X}$ & $\mathrm{X}$ \\
\hline controls for personality: $O C E A N$ & $\mathrm{X}$ & $\mathrm{X}$ & & & & \\
\hline $\begin{array}{l}\text { controls for work attitudes } \\
\text { controls for family }\end{array}$ & & & $\mathrm{X}$ & $\mathrm{X}$ & $\mathrm{X}$ & $\mathrm{X}$ \\
\hline Constant & $\begin{array}{c}4.674 * * * \\
(0.102)\end{array}$ & $\begin{array}{l}4.611 * * * \\
(0.063)\end{array}$ & $\begin{array}{l}4.635^{* * *} \\
(0.102)\end{array}$ & $\begin{array}{c}4.539 * * * \\
(0.059)\end{array}$ & $\begin{array}{l}4.705^{* * *} \\
(0.097)\end{array}$ & $\begin{array}{c}4.542^{* * *} \\
(0.060)\end{array}$ \\
\hline Adj. $R^{2}$ & 0.339 & 0.456 & 0.350 & 0.476 & 0.332 & 0.459 \\
\hline F-statistic & 12.435 & 28.129 & 14.857 & 34.881 & 13.807 & 32.648 \\
\hline Observations & 336 & 486 & 336 & 486 & 336 & 486 \\
\hline B. & $\begin{array}{l}\text { High-level } \\
\text { manager }\end{array}$ & $\begin{array}{l}\text { Mid-level } \\
\text { manager }\end{array}$ & $\begin{array}{l}\text { High-level } \\
\text { manager }\end{array}$ & $\begin{array}{l}\text { Mid-level } \\
\text { manager }\end{array}$ & $\begin{array}{l}\text { High-level } \\
\text { manager }\end{array}$ & $\begin{array}{l}\text { Mid-level } \\
\text { manager }\end{array}$ \\
\hline female manager & $\begin{array}{c}0.012 \\
(0.025)\end{array}$ & $\begin{array}{l}-0.055^{* * *} \\
(0.019)\end{array}$ & $\begin{array}{c}0.020 \\
(0.027)\end{array}$ & $\begin{array}{l}-0.057 * * * \\
(0.020)\end{array}$ & $\begin{array}{c}0.025 \\
(0.027)\end{array}$ & $\begin{array}{c}-0.051^{* * *} \\
(0.019)\end{array}$ \\
\hline controls for employee-specific characteristics & $\mathrm{X}$ & $\mathrm{X}$ & $\mathrm{X}$ & $\mathrm{X}$ & & \\
\hline controls for establishment-specific character. & $\mathrm{X}$ & $\mathrm{X}$ & $\mathrm{X}$ & $\mathrm{X}$ & & \\
\hline control for share of women in occupation & $\mathrm{X}$ & $\mathrm{X}$ & $\mathrm{X}$ & $\mathrm{X}$ & & \\
\hline controls for work task & $\mathrm{X}$ & $\mathrm{X}$ & & & & \\
\hline $\begin{array}{l}\text { controls for share of women in establishment } \\
\text { all controls }\end{array}$ & & & $\mathrm{X}$ & $\mathrm{X}$ & $\mathrm{X}$ & $\mathrm{X}$ \\
\hline Constant & $\begin{array}{c}4.752 * * * \\
(0.095)\end{array}$ & $\begin{array}{c}4.597 * * * \\
(0.061)\end{array}$ & $\begin{array}{c}4.804 * * * \\
(0.100)\end{array}$ & $\begin{array}{c}4.581 * * * \\
(0.059)\end{array}$ & $\begin{array}{c}4.794 * * * \\
(0.107)\end{array}$ & $\begin{array}{c}4.613 * * * \\
(0.070)\end{array}$ \\
\hline Adj. $R^{2}$ & 0.398 & 0.494 & 0.358 & 0.456 & 0.413 & 0.507 \\
\hline F-statistic & 15.791 & 32.546 & 17.98 & 37.900 & 9.746 & 19.498 \\
\hline Observations & 336 & 486 & 336 & 486 & 336 & 486 \\
\hline
\end{tabular}


Variables

Female manager

Manager high or middle level

Employee-specific characteristics

Years of education

Years of labor market exp.

Years of tenure
Hourly wage (SEK)

Description

Answer yes or no to the question "Is your immediate manager a man or a woman?"

Answer yes or no to the question "Is your immediate manager the highest manager in the workplace?"

A continuous variable for the gross hourly wage (recalculated as the hourly wage for all categories of respondents' reply: fixed monthly pay, fixed weekly pay, fixed hourly wage, individual or group piece rate or incentive pay

Establishment-specific characteristics

Public sector

A dummy variable equal to 1 if the respondent works in the public sector and 0 otherwise

Establishment $>100$ employees A dummy variable equal to 1 if the respondent estimate the workplace to have 100 or more employees and 0 otherwise

Part-time

Job qualifications

A dummy variable equal to 1 if the respondent works part time and 0 otherwise The number of years of education above basic education required for the job (self reported)

Share of women in occupation A continuous variable for the share of women in the occupation based on 3digit occupational code (SSYK)

Source: Swedish Level of Living Survey (2010). 


\section{Appendix Tables}

\begin{tabular}{|c|c|c|c|c|c|c|c|c|c|c|}
\hline & All & $\begin{array}{c}\text { High-level } \\
\text { manager }\end{array}$ & $\begin{array}{c}\text { Mid-level } \\
\text { manager }\end{array}$ & $\begin{array}{c}\text { High-level } \\
\text { manager }\end{array}$ & $\begin{array}{c}\text { Mid-level } \\
\text { manager }\end{array}$ & $\begin{array}{c}\text { High-level } \\
\text { manager }\end{array}$ & $\begin{array}{c}\text { Mid-level } \\
\text { manager }\end{array}$ & $\begin{array}{c}\text { High-level } \\
\text { manager }\end{array}$ & $\begin{array}{c}\text { Mid-level } \\
\text { manager }\end{array}$ & All \\
\hline female manager & $\begin{array}{c}-0.083 * * * \\
(0.018)\end{array}$ & $\begin{array}{l}-0.043 \\
(0.029)\end{array}$ & $\begin{array}{c}-0.124 * * * \\
(0.023)\end{array}$ & $\begin{array}{l}-0.048^{*} \\
(0.026)\end{array}$ & $\begin{array}{c}-0.116^{* * *} \\
(0.020)\end{array}$ & $\begin{array}{l}-0.025 \\
(0.025)\end{array}$ & $\begin{array}{c}-0.073 * * * \\
(0.018)\end{array}$ & $\begin{array}{l}-0.010 \\
(0.026)\end{array}$ & $\begin{array}{c}-0.061 * * * \\
(0.019)\end{array}$ & $\begin{array}{c}-0.036^{* *} \\
(0.015)\end{array}$ \\
\hline years of education & & & & $\begin{array}{c}0.032 * * * \\
(0.005)\end{array}$ & $\begin{array}{c}0.036 * * * \\
(0.003)\end{array}$ & $\begin{array}{c}0.009 \\
(0.006)\end{array}$ & $\begin{array}{c}0.019 * * * \\
(0.003)\end{array}$ & $\begin{array}{c}0.006 \\
(0.006)\end{array}$ & $\begin{array}{c}0.019^{* * *} \\
(0.003)\end{array}$ & $\begin{array}{c}0.015^{* * *} * \\
(0.003)\end{array}$ \\
\hline labor market experience & & & & $\begin{array}{c}0.017 * * * \\
(0.004)\end{array}$ & $\begin{array}{c}0.015^{* * *} \\
(0.003)\end{array}$ & $\begin{array}{c}0.012 * * * \\
(0.003)\end{array}$ & $\begin{array}{c}0.016^{* * *} * \\
(0.003)\end{array}$ & $\begin{array}{c}0.013 * * * \\
(0.003)\end{array}$ & $\begin{array}{c}0.016^{* * *} \\
(0.003)\end{array}$ & $\begin{array}{c}0.014 * * * \\
(0.002)\end{array}$ \\
\hline labor market exp. squared & & & & $\begin{array}{c}-0.000 * * * \\
(0.000)\end{array}$ & $\begin{array}{c}-0.000 * * * \\
(0.000)\end{array}$ & $\begin{array}{c}-0.000 * * \\
(0.000)\end{array}$ & $\begin{array}{c}-0.000^{* * * *} \\
(0.000)\end{array}$ & $\begin{array}{c}-0.000^{* *} \\
(0.000)\end{array}$ & $\begin{array}{c}-0.000 * * * \\
(0.000)\end{array}$ & $\begin{array}{c}-0.000 * * * \\
(0.000)\end{array}$ \\
\hline tenure & & & & $\begin{array}{c}0.002 \\
(0.001)\end{array}$ & $\begin{array}{l}0.002^{*} \\
(0.001)\end{array}$ & $\begin{array}{c}0.002 \\
(0.001)\end{array}$ & $\begin{array}{c}0.001 \\
(0.001)\end{array}$ & $\begin{array}{c}0.001 \\
(0.001)\end{array}$ & $\begin{array}{c}0.001 \\
(0.001)\end{array}$ & $\begin{array}{l}0.001 * \\
(0.001)\end{array}$ \\
\hline public sector & & & & & & $\begin{array}{c}-0.088 * * * \\
(0.026)\end{array}$ & $\begin{array}{c}-0.130 * * * \\
(0.018)\end{array}$ & $\begin{array}{c}-0.070 * * \\
(0.027)\end{array}$ & $\begin{array}{c}-0.120 * * * \\
(0.019)\end{array}$ & $\begin{array}{c}-0.100 * * * \\
(0.016)\end{array}$ \\
\hline establishment $>100$ employees & & & & & & $\begin{array}{c}0.100^{* * *} * \\
(0.036)\end{array}$ & $\begin{array}{c}0.058^{* * *} \\
(0.017)\end{array}$ & $\begin{array}{c}0.085 * * \\
(0.037)\end{array}$ & $\begin{array}{c}0.057 * * * \\
(0.017)\end{array}$ & $\begin{array}{c}0.078^{* * *} \\
(0.015)\end{array}$ \\
\hline part-time & & & & & & $\begin{array}{l}-0.036 \\
(0.026)\end{array}$ & $\begin{array}{c}-0.018 \\
(0.019)\end{array}$ & $\begin{array}{l}-0.033 \\
(0.026)\end{array}$ & $\begin{array}{c}-0.011 \\
(0.019)\end{array}$ & $\begin{array}{c}-0.027^{*} \\
(0.016)\end{array}$ \\
\hline job qualifications & & & & & & $\begin{array}{c}0.036 * * * \\
(0.006)\end{array}$ & $\begin{array}{c}0.038 * * * \\
(0.004)\end{array}$ & $\begin{array}{c}0.037 * * * \\
(0.006)\end{array}$ & $\begin{array}{c}0.038 * * * \\
(0.004)\end{array}$ & $\begin{array}{c}0.037 * * * \\
(0.003)\end{array}$ \\
\hline share of women in occupation & & & & & & & & $\begin{array}{c}-0.136^{* *} \\
(0.057)\end{array}$ & $\begin{array}{c}-0.085^{* *} \\
(0.036)\end{array}$ & $\begin{array}{c}-0.096 * * * \\
(0.031)\end{array}$ \\
\hline constant & $\begin{array}{c}5.059^{* * *} \\
(0.014)\end{array}$ & $\begin{array}{c}4.994 * * * \\
(0.022)\end{array}$ & $\begin{array}{c}5.115 * * * \\
(0.018)\end{array}$ & $\begin{array}{c}4.322 * * * \\
(0.080)\end{array}$ & $\begin{array}{c}4.410 * * * \\
(0.060)\end{array}$ & $\begin{array}{c}4.593 * * * \\
(0.086)\end{array}$ & $\begin{array}{c}4.540 * * * \\
(0.057)\end{array}$ & $\begin{array}{c}4.703 * * * \\
(0.097)\end{array}$ & $\begin{array}{c}4.571 * * * \\
(0.058)\end{array}$ & $\begin{array}{c}4.594^{* * *} \\
(0.050)\end{array}$ \\
\hline $\mathrm{R}$ squared & 0.025 & 0.007 & 0.057 & 0.218 & 0.289 & 0.346 & 0.461 & 0.357 & 0.467 & 0.408 \\
\hline Adjusted R squared & 0.023 & 0.004 & 0.055 & 0.206 & 0.281 & 0.328 & 0.451 & 0.338 & 0.456 & 0.401 \\
\hline F-value & 20.753 & 2.186 & 29.169 & 18.367 & 38.980 & 19.164 & 45.270 & 18.066 & 41.668 & 55.929 \\
\hline Observations & 822 & 336 & 486 & 336 & 486 & 336 & 486 & 336 & 486 & 822 \\
\hline
\end{tabular}




\begin{tabular}{ll} 
Variable: & Description \\
\hline Noncognitive traits: OCEAN & \\
Openness & $\begin{array}{l}\text { A dummy variable equal to } 1 \text { if respondent's answer is below } 2.5 \text { based on } \\
\text { the sum of the answers to "I have an active imagination" and "I have no } \\
\text { artistic interests" on a scale in which 1="disagree", } 2=\text { ="disagree somewhat", } \\
\text { 3="neither or", 4="agree somewhat", 5="fully agree", and 0 otherwise }\end{array}$
\end{tabular}

Conscientiousness

A dummy variable equal to 1 if respondent's answer is above 3.5 based on the sum of the answers to "I tend to be lazy" and "I do things thoroughly" on a scale in which $1=$ "disagree", $2=$ "disagree somewhat", $3=$ "neither or", $4=$ "agree somewhat", $5=$ "fully agree", and 0 otherwise

Extroversion

Agreeableness

Neuroticism
A dummy variable equal to 1 if respondent's answer is above 3.5 based on the sum of the answers to "I am outgoing and social" and "I am reserved" on a scale in which $1=$ "disagree", $2=$ "disagree somewhat", $3=$ "neither or", $4=$ "agree somewhat", $5=$ "fully agree", and 0 otherwise

A dummy variable equal to 1 if respondent's answer is above 3.5 based on the sum of the answers to "I often find faults in others" and "I tend to trust others" on a scale in which 1="disagree", 2="disagree somewhat", $3=$ "neither or", 4="agree somewhat", $5=$ ="fully agree", and 0 otherwise

A dummy variable equal to 1 if respondent's answer is below 3.5 based on the sum of the answers to "I easily become nervous" and "I handle stress well" on a scale in which 1="disagree", $2=$ "disagree somewhat", $3=$ "neither or", 4="agree somewhat", $5=$ "fully agree", and 0 otherwise

\section{Noncognitive traits: work attitudes}

Willingness to lead (1=agree somewhat of fully, $0=$ disagree to neither or)
A dummy variable equal to 1 if the respondent's answer is 4 or above to the statement "I am a natural leader" on a scale in which 1="disagree", $2=$ "disagree somewhat", $3=$ "neither or", 4="agree somewhat", 5="fully agree", and 0 otherwise

Willingness to persevere/effort A dummy variable equal to 1 if the sum of the respondent's answers is $(1=$ agree somewhat of fully, $0=$ disagree to neither or) above 3.7 to the statements "I do not give up when setback", "I tend to get things done easily" and "I always finish what I started" on a scale in which $1=$ "disagree", 2="disagree somewhat", $3=$ "neither or", 4="agree somewhat", $5=$ "fully agree", and 0 otherwise

Work commitment $(1=>1$ hour per week, 0 no hours)
A dummy variable equal to 1 if the respondent's reply is above 1 to the question "If you did not need the wage, how much would you work?" on a scale in which 1="not work at all", $2=$ "1-10 hours/week", $3=$ "11-20 hours/week", 4="21-34 hours/week", 5="35-40 hours/week", 6="above 40 hours/week", and 0 otherwise 
APPENDIX TABLE 4 DESCRIPTION OF THE FAMILY VARIABLES, WORK TASKS AND GENDER COMPOSITION OF THE ESTABLISHMENT

\begin{tabular}{ll}
\hline Variable: & Description \\
\hline Family variables: & \\
Married or cohabiting & A dummy variable equal to 1 if the respondent is married or cohabitates, and
\end{tabular}
0 otherwise

Number of children in the household

Small children dummy

Work tasks

Work with people (nonmanagerial)

$(1=$ all of the time or almost always, $0=$ no time to more than half of the time)
A continuous variable for the number of children in the household

A dummy variable equal to 1 if the respondent has 1 child younger than 7 years of age in the household, and 0 otherwise

A dummy variable equal to 1 if the respondent replies "all of the time or almost always" (5) on the question "How much of your working time do you work with customers, patients, pupils, or other people apart from other personnel?" on a scale in which $1=$ "no time or very seldom", $2=$ "some time but less than half", $3=$ "approximately half of the time", $4=$ "more than half of the time", $5=$ "all the time or almost always", and 0 otherwise

A dummy variable equal to 1 if the respondent's reply is above 1 on the question "How much of your working time do you work with emotionally demanding tasks?" on a scale in which 1="no time or very seldom", $2=$ "some time but less than half", $3=$ "approximately half of the time", $4=$ "more than half of the time", $5=$ "all the time or almost always", and 0 otherwise

A dummy variable equal to 1 if the respondent's reply is above 1 on the question "How much of your working time do you manage other personnel's work, such as steering, instructing, coordinating or similar?" on a scale in which 1="no time or very seldom", $2=$ "some time but less than half", $3=$ "approximately half of the time", $4=$ "more than half of the time", $5=$ "all the time or almost always", and 0 otherwise

A dummy variable equal to 1 if the respondent replies "all of the time or almost always" (5) on the question "How much of your working time do you work with text and or numbers, such as writing, counting, reading, editing or similar?" on a scale where 1="no time or very seldom", $2=$ "some time but less than half", $3=$ "approximately half of the time", $4=$ "more than half of the time", $5=$ "all the time or almost always", and 0 otherwise

A dummy variable equal to 1 if the respondent's reply is above 1 on the question "How much of your working time do you work with items or other material, such as manufacturing, building, preparing, cleaning, repairing, packing, transporting or similar tasks?" on a scale where $1=$ "no time or very seldom", $2=$ "some time but less than half", $3=$ "approximately half of the time", 4="more than half of the time", $5=$ "all the time or almost always", and 0 otherwise

\section{Gender composition of the establishment}

Share of women in the

A continuous variable for the share of women in the establishment establishment 
APPENDIX TABLE 5. WAGE REGRESSIONS ADDING NONCOGNITIVE TRAITS

\begin{tabular}{|c|c|c|c|c|}
\hline & $\begin{array}{l}\text { High-level } \\
\text { manager }\end{array}$ & $\begin{array}{l}\text { Mid-level } \\
\text { manager }\end{array}$ & $\begin{array}{l}\text { High-level } \\
\text { manager }\end{array}$ & $\begin{array}{l}\text { Mid-level } \\
\text { manager }\end{array}$ \\
\hline & $\begin{array}{c}\text { add } \\
\text { OCEAN }\end{array}$ & $\begin{array}{c}\text { add } \\
\text { OCEAN }\end{array}$ & $\begin{array}{c}\text { add } \\
\text { work attitudes }\end{array}$ & $\begin{array}{c}\text { add } \\
\text { work attitudes }\end{array}$ \\
\hline female manager & $\begin{array}{l}-0.009 \\
(0.026)\end{array}$ & $\begin{array}{c}-0.062 * * * \\
(0.019)\end{array}$ & $\begin{array}{l}-0.019 \\
(0.026)\end{array}$ & $\begin{array}{c}-0.066 * * * \\
(0.019)\end{array}$ \\
\hline openness & $\begin{array}{c}0.018 \\
(0.035)\end{array}$ & $\begin{array}{c}-0.049 * * \\
(0.025)\end{array}$ & & \\
\hline conscientiousness & $\begin{array}{c}0.030 \\
(0.026)\end{array}$ & $\begin{array}{c}0.013 \\
(0.018)\end{array}$ & & \\
\hline extroversion & $\begin{array}{c}0.008 \\
(0.025)\end{array}$ & $\begin{array}{c}0.008 \\
(0.018)\end{array}$ & & \\
\hline agreeableness & $\begin{array}{c}0.026 \\
(0.025)\end{array}$ & $\begin{array}{l}-0.007 \\
(0.018)\end{array}$ & & \\
\hline neuroticism & $\begin{array}{l}-0.039 \\
(0.032)\end{array}$ & $\begin{array}{l}-0.013 \\
(0.022)\end{array}$ & & \\
\hline willingness to lead & & & $\begin{array}{l}0.046^{*} \\
(0.026)\end{array}$ & $\begin{array}{c}0.079 * * * \\
(0.018)\end{array}$ \\
\hline willingness to persevere/effort & & & $\begin{array}{l}0.048 * \\
(0.025)\end{array}$ & $\begin{array}{c}0.007 \\
(0.017)\end{array}$ \\
\hline work commitment & & & $\begin{array}{c}0.020 \\
(0.033)\end{array}$ & $\begin{array}{c}0.026 \\
(0.023)\end{array}$ \\
\hline years of education & $\begin{array}{c}0.006 \\
(0.006)\end{array}$ & $\begin{array}{c}0.019 * * * \\
(0.004)\end{array}$ & $\begin{array}{c}0.006 \\
(0.006)\end{array}$ & $\begin{array}{c}0.017 * * * \\
(0.003)\end{array}$ \\
\hline labor market experience & $\begin{array}{c}0.012 * * * \\
(0.003)\end{array}$ & $\begin{array}{c}0.015 * * * \\
(0.003)\end{array}$ & $\begin{array}{c}0.012 * * * \\
(0.003)\end{array}$ & $\begin{array}{c}0.015 * * * \\
(0.003)\end{array}$ \\
\hline labor market exp. squared & $\begin{array}{l}-0.000 * \\
(0.000)\end{array}$ & $\begin{array}{c}-0.000 * * * \\
(0.000)\end{array}$ & $\begin{array}{c}-0.000 * * \\
(0.000)\end{array}$ & $\begin{array}{c}-0.000 * * * \\
(0.000)\end{array}$ \\
\hline tenure & $\begin{array}{c}0.001 \\
(0.001)\end{array}$ & $\begin{array}{c}0.001 \\
(0.001)\end{array}$ & $\begin{array}{c}0.001 \\
(0.001)\end{array}$ & $\begin{array}{c}0.001 \\
(0.000)\end{array}$ \\
\hline public sector & $\begin{array}{c}-0.067 * * \\
(0.027)\end{array}$ & $\begin{array}{c}-0.117 * * * \\
(0.019)\end{array}$ & $\begin{array}{c}-0.066^{* *} \\
(0.027)\end{array}$ & $\begin{array}{c}-0.121 * * * \\
(0.018)\end{array}$ \\
\hline establishment $>100$ employees & $\begin{array}{c}0.075 * * \\
(0.037)\end{array}$ & $\begin{array}{c}0.055 * * * \\
(0.017)\end{array}$ & $\begin{array}{c}0.084 * * \\
(0.036)\end{array}$ & $\begin{array}{c}0.056^{* * *} * \\
(0.017)\end{array}$ \\
\hline part-time & $\begin{array}{c}-0.028 \\
(0.026)\end{array}$ & $\begin{array}{c}-0.011 \\
(0.019)\end{array}$ & $\begin{array}{l}-0.023 \\
(0.026)\end{array}$ & $\begin{array}{c}-0.004 \\
(0.019)\end{array}$ \\
\hline job qualifications & $\begin{array}{c}0.036 * * * \\
(0.006)\end{array}$ & $\begin{array}{c}0.038 * * * \\
(0.004)\end{array}$ & $\begin{array}{c}0.036 * * * \\
(0.006)\end{array}$ & $\begin{array}{c}0.038 * * * \\
(0.004)\end{array}$ \\
\hline share of women in occupation & $\begin{array}{c}-0.136^{* *} \\
(0.057)\end{array}$ & $\begin{array}{c}-0.087 * * \\
(0.036)\end{array}$ & $\begin{array}{c}-0.120 * * \\
(0.057)\end{array}$ & $\begin{array}{l}-0.070 * \\
(0.036)\end{array}$ \\
\hline constant & $\begin{array}{c}4.674 * * * \\
(0.102)\end{array}$ & $\begin{array}{c}4.611 * * * \\
(0.063)\end{array}$ & $\begin{array}{c}4.635 * * * \\
(0.102)\end{array}$ & $\begin{array}{c}4.539 * * * \\
(0.059)\end{array}$ \\
\hline R squared & 0.368 & 0.473 & 0.375 & 0.490 \\
\hline Adjusted R squared & 0.339 & 0.456 & 0.350 & 0.476 \\
\hline F-value & 12.435 & 28.129 & 14.857 & 34.881 \\
\hline Observations & 336 & 486 & 336 & 486 \\
\hline
\end{tabular}

Note: Standard errors are in parentheses. "High-level manager" refers to the manager being the highest manager in the establishment, whereas "mid-level manager" refers to the manager not being the highest manager in the establishment. Detailed variable description is given in Appendix Table 1 and Appendix Table 3.

* Statistically significant at the .10 level; ** at the .05 level; *** at the .01 level.

Source: Swedish Level of Living Survey, 2010. 
APPENDIX TABLE 5 cont. WAGE REGRESSIONS ADDING FAMILY VARIABLES, WORK TASK AND GENDER COMPOSITION OF THE ESTABLISHMENT

\begin{tabular}{|c|c|c|c|c|c|c|}
\hline & $\begin{array}{l}\text { High-level } \\
\text { manager }\end{array}$ & $\begin{array}{l}\text { Mid-level } \\
\text { manager }\end{array}$ & $\begin{array}{l}\text { High-level } \\
\text { manager }\end{array}$ & $\begin{array}{l}\text { Mid-level } \\
\text { manager }\end{array}$ & $\begin{array}{l}\text { High-level } \\
\text { manager }\end{array}$ & $\begin{array}{l}\text { Mid-level } \\
\text { manager }\end{array}$ \\
\hline & $\begin{array}{c}\text { add } \\
\text { family } \\
\text { commit- } \\
\text { ment }\end{array}$ & $\begin{array}{c}\text { add } \\
\text { family } \\
\text { commit- } \\
\text { ment }\end{array}$ & $\begin{array}{c}\text { add } \\
\text { work task }\end{array}$ & $\begin{array}{c}\text { add } \\
\text { work task }\end{array}$ & $\begin{array}{c}\text { add } \\
\text { share of } \\
\text { females in } \\
\text { establ. }\end{array}$ & $\begin{array}{c}\text { add } \\
\text { share of } \\
\text { females in } \\
\text { establ. }\end{array}$ \\
\hline female manager & $\begin{array}{l}-0.009 \\
(0.026)\end{array}$ & $\begin{array}{c}-0.057 * * * \\
(0.019)\end{array}$ & $\begin{array}{c}0.012 \\
(0.025)\end{array}$ & $\begin{array}{c}-0.055 * * * \\
(0.019)\end{array}$ & $\begin{array}{c}0.020 \\
(0.027)\end{array}$ & $\begin{array}{c}-0.057 * * * \\
(0.020)\end{array}$ \\
\hline married/cohabitating & $\begin{array}{l}-0.003 \\
(0.029)\end{array}$ & $\begin{array}{c}0.020 \\
(0.021)\end{array}$ & & & & \\
\hline $\begin{array}{l}\text { number of children in } \\
\text { household }\end{array}$ & $\begin{array}{c}0.006 \\
(0.015)\end{array}$ & $\begin{array}{c}0.013 \\
(0.010)\end{array}$ & & & & \\
\hline small children & $\begin{array}{c}0.004 \\
(0.039)\end{array}$ & $\begin{array}{c}0.014 \\
(0.025)\end{array}$ & & & & \\
\hline work with people (non-man.) & & & $\begin{array}{l}-0.034 \\
(0.027)\end{array}$ & $\begin{array}{l}-0.025 \\
(0.020)\end{array}$ & & \\
\hline emotionally demanding work & & & $\begin{array}{l}-0.047^{*} \\
(0.029)\end{array}$ & $\begin{array}{c}0.019 \\
(0.021)\end{array}$ & & \\
\hline managerial work & & & $\begin{array}{c}0.122 * * * \\
(0.025)\end{array}$ & $\begin{array}{c}0.081 * * * \\
(0.018)\end{array}$ & & \\
\hline work with text/digits & & & $\begin{array}{c}0.009 \\
(0.028)\end{array}$ & $\begin{array}{c}0.027 \\
(0.020)\end{array}$ & & \\
\hline manual work & & & $\begin{array}{c}-0.069 * * * \\
(0.025)\end{array}$ & $\begin{array}{c}-0.061 * * * \\
(0.019)\end{array}$ & & \\
\hline share of women in establish. & & & & & $\begin{array}{c}-0.237 * * * \\
(0.070)\end{array}$ & $\begin{array}{l}-0.038 \\
(0.050)\end{array}$ \\
\hline years of education & $\begin{array}{c}0.006 \\
(0.006)\end{array}$ & $\begin{array}{c}0.020 * * * \\
(0.003)\end{array}$ & $\begin{array}{c}0.004 \\
(0.006)\end{array}$ & $\begin{array}{c}0.016 * * * \\
(0.003)\end{array}$ & $\begin{array}{c}0.007 \\
(0.006)\end{array}$ & $\begin{array}{c}0.019 * * * \\
(0.003)\end{array}$ \\
\hline labor market experience & $\begin{array}{c}0.012 * * * \\
(0.004)\end{array}$ & $\begin{array}{c}0.014 * * * \\
(0.003)\end{array}$ & $\begin{array}{c}0.010 * * * \\
(0.003)\end{array}$ & $\begin{array}{c}0.015 * * * \\
(0.003)\end{array}$ & $\begin{array}{c}0.013 * * * \\
(0.003)\end{array}$ & $\begin{array}{c}0.016 * * * \\
(0.003)\end{array}$ \\
\hline labor market exp. squared & $\begin{array}{c}-0.000 * * \\
(0.000)\end{array}$ & $\begin{array}{c}-0.000 * * * \\
(0.000)\end{array}$ & $\begin{array}{l}-0.000 * \\
(0.000)\end{array}$ & $\begin{array}{c}-0.000 * * * \\
(0.000)\end{array}$ & $\begin{array}{c}-0.000 * * \\
(0.000)\end{array}$ & $\begin{array}{c}-0.000 * * * \\
(0.000)\end{array}$ \\
\hline tenure & $\begin{array}{c}0.001 \\
(0.001)\end{array}$ & $\begin{array}{c}0.001 \\
(0.001)\end{array}$ & $\begin{array}{c}0.001 \\
(0.001)\end{array}$ & $\begin{array}{c}0.001 \\
(0.001)\end{array}$ & $\begin{array}{c}0.001 \\
(0.001)\end{array}$ & $\begin{array}{c}0.001 \\
(0.001)\end{array}$ \\
\hline public sector & $\begin{array}{c}-0.069 * * \\
(0.027)\end{array}$ & $\begin{array}{c}-0.123 * * * \\
(0.019)\end{array}$ & $\begin{array}{l}-0.042 \\
(0.027)\end{array}$ & $\begin{array}{c}-0.111 * * * \\
(0.020)\end{array}$ & $\begin{array}{c}-0.046^{*} \\
(0.028)\end{array}$ & $\begin{array}{c}-0.113 * * * \\
(0.021)\end{array}$ \\
\hline establishment $>100$ employees & $\begin{array}{c}0.083 * * \\
(0.037)\end{array}$ & $\begin{array}{c}0.059 * * * \\
(0.017)\end{array}$ & $\begin{array}{l}0.064 * \\
(0.035)\end{array}$ & $\begin{array}{c}0.049 * * * \\
(0.017)\end{array}$ & $\begin{array}{c}0.086 * * \\
(0.036)\end{array}$ & $\begin{array}{c}0.057 * * * \\
(0.017)\end{array}$ \\
\hline part-time & $\begin{array}{c}-0.034 \\
(0.026)\end{array}$ & $\begin{array}{l}-0.015 \\
(0.019)\end{array}$ & $\begin{array}{l}-0.017 \\
(0.025)\end{array}$ & $\begin{array}{c}0.006 \\
(0.019)\end{array}$ & $\begin{array}{l}-0.017 \\
(0.026)\end{array}$ & $\begin{array}{l}-0.009 \\
(0.020)\end{array}$ \\
\hline job qualifications & $\begin{array}{c}0.037 * * * \\
(0.006)\end{array}$ & $\begin{array}{c}0.037 * * * \\
(0.004)\end{array}$ & $\begin{array}{c}0.033 * * * \\
(0.006)\end{array}$ & $\begin{array}{c}0.032 * * * \\
(0.004)\end{array}$ & $\begin{array}{c}0.037 * * * \\
(0.006)\end{array}$ & $\begin{array}{c}0.038 * * * \\
(0.004)\end{array}$ \\
\hline share of women in occupation & $\begin{array}{c}-0.140 * * \\
(0.058)\end{array}$ & $\begin{array}{c}-0.089 * * \\
(0.036)\end{array}$ & $\begin{array}{l}-0.092 * \\
(0.056)\end{array}$ & $\begin{array}{l}-0.052 \\
(0.037)\end{array}$ & $\begin{array}{l}-0.108 * \\
(0.057)\end{array}$ & $\begin{array}{c}-0.079 * * \\
(0.037)\end{array}$ \\
\hline constant & $\begin{array}{c}4.705 * * * \\
(0.097)\end{array}$ & $\begin{array}{c}4.542 * * * \\
(0.060)\end{array}$ & $\begin{array}{c}4.752 * * * \\
(0.095)\end{array}$ & $\begin{array}{c}4.597 * * * \\
(0.061)\end{array}$ & $\begin{array}{c}4.804 * * * \\
(0.100)\end{array}$ & $\begin{array}{c}4.581 * * * \\
(0.059)\end{array}$ \\
\hline R squared & 0.358 & 0.473 & 0.425 & 0.509 & 0.379 & 0.468 \\
\hline Adjusted R squared & 0.332 & 0.459 & 0.398 & 0.494 & 0.358 & 0.456 \\
\hline F-value & 13.807 & 32.648 & 15.791 & 32.546 & 17.985 & 37.899 \\
\hline Observations & 336 & 486 & 336 & 486 & 336 & 486 \\
\hline
\end{tabular}




\begin{tabular}{|c|c|c|c|c|c|c|c|}
\hline & $\begin{array}{c}\text { High-level } \\
\text { manager }\end{array}$ & $\begin{array}{c}\text { Mid-level } \\
\text { manager }\end{array}$ & All & & $\begin{array}{c}\text { High-level } \\
\text { manager }\end{array}$ & $\begin{array}{c}\text { Mid-level } \\
\text { manager }\end{array}$ & All \\
\hline female manager & $\begin{array}{c}0.025 \\
(0.027)\end{array}$ & $\begin{array}{c}-0.051 * * * \\
(0.019)\end{array}$ & $\begin{array}{l}-0.019 \\
(0.015)\end{array}$ & no of children in household & $\begin{array}{c}0.005 \\
(0.014)\end{array}$ & $\begin{array}{c}0.008 \\
(0.010)\end{array}$ & $\begin{array}{c}0.005 \\
(0.008)\end{array}$ \\
\hline work with people (non-man.) & $\begin{array}{l}-0.031 \\
(0.027)\end{array}$ & $\begin{array}{l}-0.028 \\
(0.020)\end{array}$ & $\begin{array}{l}-0.029^{*} \\
(0.016)\end{array}$ & small children & $\begin{array}{c}0.015 \\
(0.037)\end{array}$ & $\begin{array}{c}0.017 \\
(0.024)\end{array}$ & $\begin{array}{c}0.009 \\
(0.020)\end{array}$ \\
\hline emotionally demanding work & $\begin{array}{l}-0.040 \\
(0.029)\end{array}$ & $\begin{array}{c}0.020 \\
(0.021)\end{array}$ & $\begin{array}{l}-0.004 \\
(0.017)\end{array}$ & share of women in establishment & $\begin{array}{c}-0.197 * * * \\
(0.071)\end{array}$ & $\begin{array}{l}-0.048 \\
(0.049)\end{array}$ & $\begin{array}{c}-0116^{* * *} \\
(0.040)\end{array}$ \\
\hline managerial work & $\begin{array}{c}0.120^{* * *} \\
(0.025)\end{array}$ & $\begin{array}{c}0.070^{* * *} \\
(0.018)\end{array}$ & $\begin{array}{c}0.089 * * * \\
(0.015)\end{array}$ & years of education & $\begin{array}{c}0.005 \\
(0.006)\end{array}$ & $\begin{array}{c}0.016^{* * *} \\
(0.003)\end{array}$ & $\begin{array}{c}0.013 * * * \\
(0.003)\end{array}$ \\
\hline work with text/digits & $\begin{array}{c}0.004 \\
(0.028)\end{array}$ & $\begin{array}{c}0.028 \\
(0.020)\end{array}$ & $\begin{array}{c}0.020 \\
(0.016)\end{array}$ & labor market experience & $\begin{array}{c}0.010^{* * *} \\
(0.004)\end{array}$ & $\begin{array}{c}0.014 * * * \\
(0.003)\end{array}$ & $\begin{array}{c}0.013 * * * \\
(0.002)\end{array}$ \\
\hline manual work (or with items) & $\begin{array}{c}-0.064 * * \\
(0.025)\end{array}$ & $\begin{array}{c}-0.059 * * * \\
(0.020)\end{array}$ & $\begin{array}{c}-0.068 * * * \\
(0.015)\end{array}$ & labor market exp. squared & $\begin{array}{c}-0.000 \\
(0.000)\end{array}$ & $\begin{array}{c}-0.000 * * * \\
(0.000)\end{array}$ & $\begin{array}{c}-0.000^{* * *} * \\
(0.000)\end{array}$ \\
\hline openness & $\begin{array}{l}-0.000 \\
(0.034)\end{array}$ & $\begin{array}{c}-0.050^{* *} \\
(0.024)\end{array}$ & $\begin{array}{l}-0.033^{*} \\
(0.019)\end{array}$ & tenure & $\begin{array}{c}0.001 \\
(0.001)\end{array}$ & $\begin{array}{c}0.001 \\
(0.001)\end{array}$ & $\begin{array}{c}0.001 \\
(0.001)\end{array}$ \\
\hline conscientiousness & $\begin{array}{c}0.030 \\
(0.026)\end{array}$ & $\begin{array}{l}-0.005 \\
(0.018)\end{array}$ & $\begin{array}{c}0.008 \\
(0.015)\end{array}$ & public sector & $\begin{array}{l}-0.016 \\
(0.028)\end{array}$ & $\begin{array}{c}-0.104 * * * \\
(0.021)\end{array}$ & $\begin{array}{c}-0.065 * * * \\
(0.016)\end{array}$ \\
\hline extroversion & $\begin{array}{l}-0.021 \\
(0.025)\end{array}$ & $\begin{array}{l}-0.016 \\
(0.018)\end{array}$ & $\begin{array}{l}-0.016 \\
(0.014)\end{array}$ & establishment $>100$ employees & $\begin{array}{l}0.060^{*} \\
(0.036)\end{array}$ & $\begin{array}{c}0.047 * * * \\
(0.017)\end{array}$ & $\begin{array}{c}0.058^{* * * *} \\
(0.015)\end{array}$ \\
\hline agreeableness & $\begin{array}{c}0.026 \\
(0.024)\end{array}$ & $\begin{array}{l}-0.002 \\
(0.017)\end{array}$ & $\begin{array}{c}0.008 \\
(0.014)\end{array}$ & part-time & $\begin{array}{c}0.003 \\
(0.025)\end{array}$ & $\begin{array}{c}0.011 \\
(0.019)\end{array}$ & $\begin{array}{c}0.003 \\
(0.015)\end{array}$ \\
\hline neuroticism & $\begin{array}{l}-0.008 \\
(0.031)\end{array}$ & $\begin{array}{c}0.002 \\
(0.022)\end{array}$ & $\begin{array}{c}-0.004 \\
(0.018)\end{array}$ & job qualifications & $\begin{array}{c}0.032 * * * \\
(0.006)\end{array}$ & $\begin{array}{c}0.032 * * * \\
(0.004)\end{array}$ & $\begin{array}{c}0.031 * * * \\
(0.003)\end{array}$ \\
\hline willingness to lead & $\begin{array}{c}0.038 \\
(0.025)\end{array}$ & $\begin{array}{c}0.071 * * * \\
(0.019)\end{array}$ & $\begin{array}{c}0.059 * * * \\
(0.015)\end{array}$ & share of women in occupation & $\begin{array}{c}-0.065 \\
(0.056)\end{array}$ & $\begin{array}{l}-0.037 \\
(0.037)\end{array}$ & $\begin{array}{c}-0.038 \\
(0.031)\end{array}$ \\
\hline willingness to persevere/effort & $\begin{array}{c}0.042 \\
(0.026)\end{array}$ & $\begin{array}{c}0.011 \\
(0.018)\end{array}$ & $\begin{array}{l}0.026^{*} \\
(0.015)\end{array}$ & constant & $\begin{array}{c}4.794 * * * \\
(0.107)\end{array}$ & $\begin{array}{c}4.613^{* * *} \\
(0.070)\end{array}$ & $\begin{array}{c}4.662 * * * \\
(0.057)\end{array}$ \\
\hline work commitment & $\begin{array}{l}-0.009 \\
(0.032)\end{array}$ & $\begin{array}{c}0.004 \\
(0.022)\end{array}$ & $\begin{array}{c}0.004 \\
(0.018)\end{array}$ & $\begin{array}{l}\text { R squared } \\
\text { Adjusted R squared }\end{array}$ & $\begin{array}{l}0.461 \\
0.413\end{array}$ & $\begin{array}{l}0.535 \\
0.507\end{array}$ & $\begin{array}{l}0.484 \\
0.467\end{array}$ \\
\hline married/cohabitant & $\begin{array}{l}-0.030 \\
(0.028)\end{array}$ & $\begin{array}{c}0.011 \\
(0.020)\end{array}$ & $\begin{array}{c}0.001 \\
(0.016)\end{array}$ & $\begin{array}{l}\text { F-value } \\
\text { Observations }\end{array}$ & $\begin{array}{c}9.746 \\
336\end{array}$ & $\begin{array}{c}19.498 \\
486\end{array}$ & $\begin{array}{c}27.615 \\
822\end{array}$ \\
\hline
\end{tabular}

hote: Standard manager in the establishment. Detailed variable description is given in Appendix Table 1, Appendix Table 3 and Appendix Table 4.

* Statistically significant at the .10 level; ** at the .05 level; *** at the .01 level.

Source: Swedish Level of Living Survey, 2010. 